\title{
Human papillomavirus infection and risk factors to cervical cancer in asymptomatic women in the region of the Northeast of Brazil
}

\section{Infecção pelo papillomavirus humano e fatores de risco para o cancer cervical em mulheres assintomáticas em uma região do Nordeste do Brasil}

\author{
Karol Fireman de Farias ${ }^{1}$ (D) , Adrielle Sonara Gomes Silva ${ }^{2}$ () , Ana Caroline Melo dos Santos ${ }^{3}$ (i) , Adriely Ferreira da Silva ${ }^{2}$ (D) , Denise \\ Macedo da Silva ${ }^{4}$ (D) Edilson Leite de Moura ${ }^{4}$ (D) , Alexandre Wendel de Moura Araújo ${ }^{2}$ (D), Cristiane Araújo Nascimento ${ }^{5}$, Danyelly

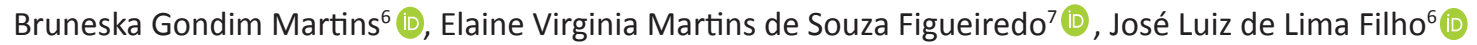

1. Graduate Program in Intellectual Property and Technology Transfer for Innovation (PROFINIT). Professor of the Bachelor of Nursing course at the Federal University of Alagoas, Campus Arapiraca, AL, Brazil. 2. Graduate in Nursing from the Federal University of Alagoas, Campus Arapiraca, AL, Brazil. 3. Postgraduate Program in Health Sciences, Federal University of Alagoas, Campus A.C. Simões, Maceió, AL, Brazil. 4. Postgraduate Program in Health Sciences, Federal University of Alagoas, Campus A.C. Simões, Maceió, AL, Brazil. 5. Postgraduate Program in Biotechnology in Health by the Northeast Biotechnology Network - RENORBIO. Federal University of Alagoas (UFAL), Maceió, AL, Brazil. 6. Keizo Asami Immunopathology Laboratory, Federal University of Pernambuco, Recife - PE, Brazil. 7. Postgraduate Program in Health Sciences, Federal University of Alagoas, Campus A. C. Simões. Professor of the Bachelor of Nursing course at the Federal University of Alagoas, Campus Arapiraca, AL, Brazil.

\begin{abstract}
Objective: This study sought to identify the presence of HPV infection and the risk factors related to susceptibility to cervical cancer in asymptomatic women. Methods: It is a cross-sectional study with 428 users attended Basic Health Units, in Arapiraca, Alagoas, Brazil. Sociodemographic, behavioral variables, and cytopathological reports were collected. Molecular detection of the HPV virus was performed by Nested-PCR. Statistical analysis was conducted with SPSS version 22.0. Results: A total of 428 women were studied, HPV DNA detected in 39.2\% ( $\mathrm{n}=168)$, with a mean age of 41 years old. There was an association of HPV with use of oral contraceptives $(\mathrm{p}<0.016)$ and alcoholism $(\mathrm{p}<0.038)$. It was showed a higher frequency of positive HPV in women older than 25 years old (88.7\%), up to 5 sexual partners (93.4\%), up to 3 pregnancies $(71.4 \%)$, and with the cytopathologic results within the limits of normality (61.9\%). HPV was identified in $40.3 \%$ (104/258) of the women with results within the limits of normality. Conclusion: Our results suggest that the use of oral contraceptives and alcoholism may be considered as possible risk factors related to cervical oncogenesis. With this, it is necessary to propose interventions aimed at the health education of this population, actions of prevention, and early detection.
\end{abstract}

Keywords: Papillomaviridae. Women's Health. Pap Smear. Cervical Neoplasms.

\section{Resumo}

Objetivo: Este estudo buscou identificar a presença de infecção pelo HPV e os fatores de risco relacionados à suscetibilidade ao câncer do colo do útero em mulheres assintomáticas. Métodos: Trata-se de um estudo transversal com 428 usuários atendidos em Unidades Básicas de Saúde, em Arapiraca, Alagoas, Brasil. Foram coletados relatórios sociodemográficos, variáveis comportamentais e citopatológicos. A detecção molecular do vírus HPV foi realizada por Nested-PCR. A análise estatística foi realizada com SPSS versão 22.0. Resultados: Foram estudadas 428 mulheres, com DNA de HPV detectado em $39,2 \%$ ( $\mathrm{n}=168$ ), com média de idade de 41 anos. Houve associação do HPV com o uso de anticoncepcional oral $(\mathrm{p}<0,016)$ e alcoolismo (p <0,038). Foi evidenciada maior frequência de HPV positivo em mulheres maiores de 25 anos (88,7\%), até cinco parceiros sexuais $(93,4 \%)$, até três gestações (71,4\%) e com resultados citopatológicos dentro dos limites da normalidade (61,9\%). 0 HPV foi identificado em 40,3\% (104/258) das mulheres com resultados dentro dos limites da normalidade. Conclusão: Nossos resultados sugerem que o uso de anticoncepcionais orais e o alcoolismo podem ser considerados como possíveis fatores de risco relacionados à oncogênese cervical. Com isso, é necessário propor intervenções voltadas para a educação em saúde dessa população, ações de prevenção e detecção precoce.

Palavras-chave: Papillomaviridae. Saúde da Mulher. Papanicolau. Neoplasias cervicais.

\section{INTRODUÇÃO}

Human papillomavirus (HPV) infection is the main risk factor for the development of cervical cancer. It is estimated that $80 \%$ of people who have an active sex life will be infected at some point in their life, once or multiple times $\underline{1}$. This virus infects the human epithelium, often transiently, and may regress between one and two years after exposure ${ }^{1,2}$.

Risk factors associated with persistent infection by some type of oncogenic HPV can lead to the development of pre-cancerous lesions that if identified and treated properly, prevent progression to cervical cancer ${ }^{3}$. There are more than 200 types of HPV recognized ${ }^{4}$, where at least 13 are considered oncogenic and associated with precursor lesions of cervical cancer, while the others are related to genital and cutaneous warts ${ }^{5}$. Cervical cancer is one of the most common cancers in the world. In 2012, 527 thousand new cases were estimated. On the world 
stage is the fourth most common cancer among women. In Latin America, it represents the second most incident and the second cause of death ${ }^{6}$.

In Brazil, according to estimates by the National Cancer Institute for the 2016/2017 biennium, 16,340 new cases of cervical cancer are expected, ranking the third position among the most common cancers in the female population and the fourth cause of death of women for cancer ${ }^{7}$. The scenario of this pathology by region remains worrying, where the incidence, without considering non-melanoma skin tumors, in the Northern Region ( 23.97 / 100 thousand) is the largest in the country. The Central-West (20.72 / 100 thousand) and Northeast (19.49 / 100 thousand) regions continue to occupy second place; the Southeast Region (11.30 / 100 thousand) the third; and the South Region (15.17 / 100 thousand), the fourth position?.

In addition to human Papillomavirus infection, other factors are related to the development of cervical cancer, such as immunological conditions, genetic conditions, sexual behavior ${ }^{2}$, age, smoking, early sexual initiation, the multiplicity of sexual partners, multiparity, and use of oral contraceptives ${ }^{8}$. Considering this context, it is realized that HPV infection is a necessary factor, which is associated with other factors that can develop this neoplasia (9). In this way, detecting the presence of HPV infection and the associated risk factors for cervical cancer susceptibility can provide women targeted clinical practice and prevention of these diseases. Thus, the objective of this study was to identify the presence of HPV infection and the risk factors related to susceptibility to cervical cancer in asymptomatic women in a region of the Brazilian Northeast.

\section{METHODS}

The project was approved by the Ethics and Research Committee of the Federal University of Alagoas under opinion 931.700 and Certificate of Presentation for Ethical Appreciation (CAAE) under registration 31450014.9.0000.5013.

\section{Subjects}

This is a descriptive and cross-sectional quantitative study performed with 428 users during the gynecological nursing consultation in Basic Family Health Units, in the city of Arapiraca, Alagoas, Brazil, between November 2014 and December 2015. The study population was composed of women selected according to the following criteria: search for oncologic colpocytology, who initiated sexual life, over 18 years of age, who were not pregnant or menstrual period, and who agreed to participate in the research and signed the Free and Informed Consent Term. The following exclusion criteria were adopted: non-continuity of the patient during the gynecological visit, hysterectomized, under 18 years and who did not accept to participate in the study. The instrument used for data collection was a semi-structured questionnaire with sociodemographic characteristics, sexual history, reproductive history, clinical history, smoking habits, and alcoholism.

The cytopathological reports were obtained from the Cervical Cancer Information System (SISCOLO), which assists the National Cancer Control Program and the Viva Mulher Program. They were classified according to the Bethesda Nomenclature in their last review, which details the descriptive nomenclature of the findings of gynecological cytology ${ }^{9}$. In the study were considered normal results those who had in their description: within the limits of normality and as altered those with benign alterations or abnormalities of epithelial cells.

\section{Molecular detection of HPV}

The biological material collected consisted of a sample of epithelial cells from the ectocervix and endocervix for oncotic colpocytology and for molecular diagnosis of endocervix cells. The samples were processed for DNA extraction using the PROMEGA commercial kit. For internal control of the reaction, PCR amplification was performed with primers specific for the human $\beta$-actin gene using the forward primer 5'-AGCGGGAAATCGTGCGTG-3 'and the reverse primer' 5-GGTGATGACCTGGCCGTC-3 ') that amplifies a region with a $134 \mathrm{bp}$ fragment. The conditions for PCR were denaturation at $95^{\circ} \mathrm{C}$ for 2 minutes; denaturation in 40 cycles at $95^{\circ} \mathrm{C}$ for 1 minute, $60^{\circ} \mathrm{C}$ for 1 minute, annealing at $72^{\circ} \mathrm{C}$ for 1 minute; extension at $72^{\circ} \mathrm{C}$ for 5 minutes. In the negative controls, ultrapure water was used.

HPV detection was performed in two steps. The first was by PCR using primers MY09 / MY11 5'CGTCCMAARGGAWACTGATC3 'and 5'GCMCAGGGWCATAAYAATGG3', which amplifies a fragment of $450 \mathrm{bp}$. The product of this reaction was used for the second step using nested-PCR technique and GP5 + / GP6 + 5'TTTGTTACTCTGGTAGATAC3 'and 5'GAAAAATAAACTGTAAATCA3', amplifying a 150 bp fragment, both of the $L 1$ region. The PCR reaction product was visualized on $2 \%$ agarose gel stained with ethidium bromide and subsequently photographed by the L.Pix Transilluminator apparatus (Loccus Biotechnology).

\section{Statistical analysis}

The database, including sociodemographic and behavioral factors, was analyzed using the Statistical Package for Social Sciences (SPSS) software version 22.0. The variables analyzed were: ethnicity, age, marital status, schooling, family income, age of first sexual intercourse, number of partners, number of pregnancies, período of the last preventive exam, current contraceptive method, history of Sexually Transmitted Infection (STI), smoking and alcohol habits. The descriptive analysis presented the frequency distributions, calculation of mean statistics, and standard deviation. Odds ratios (OR) with a $95 \%$ confidence interval $(95 \% \mathrm{Cl})$ were calculated and the Fisher exact test was used, considering that the differences were statistically significant when $\mathrm{p}<0.05$. 


\section{RESULTS}

A total of 428 SUS users accepted to participate of this study with a mean age of 41 years (DP: 13.69, minimum: 18, maximum, $79) ; 39,2 \%(n=168)$ were HPV positive, with a mean age of 45 years (SD: 14.39; minimum: 27 ; maximum: 55 ), with $25.6 \%$ ( $n=$ $43)$ with less than 29 years old; $27.4 \%(n=46)$ aged $30-39$ years; $17.3 \%(n=29)$ between $40-49$ years. There were $8.3 \%$ and $2.4 \%$ of women between $60-69$ years and $70-79$ years. Of the total women in the study $60.8 \%(n=260)$ were negative for HPV with mean age of 45 years (DP16.85, minimum: 18, maximum: 79).

Regarding ethnicity, the two groups had the majority of brown women with $61.9 \%$ of those with HPV positive and $65.4 \%$ with negative HPV. The majority of women who tested positive for HPV were married, $44.6 \%(n=75)$. Regarding schooling, the majority attended elementary school, with $47 \%(n=79)$ among those who were detected for HPV and $50 \%(n=130)$ those who had negative results. As for income below two minimum wages, this condition was observed in $81 \%(n=136)$ of women with positive HPV infection and $76.9 \%(n=200)$ of women with HPV negative. Regarding the last colpocytology examination, the frequency of women who performed the test more than one year was greater in women detected with HPV $51.8 \%(n=87)$ than those who were negative for the infection $(46.2 \% n=120)$. The demographic, sexual, and reproductive characteristics of the study sample are shown in Table 1.

Table 1. Sociodemographic characteristics of asymptomatic women in northeastern Brazil.

\begin{tabular}{lrr}
\hline Category & HPV positive N (\%) & HPV negative N (\%) \\
\hline Age Group & $43(25.6)$ & $52(20)$ \\
Up to 29 years & $46(27.4)$ & $79(30.4)$ \\
30 to 39 years & $29(17.3)$ & $56(21.5)$ \\
40 to 49 years & $32(19)$ & $47(18.1)$ \\
50 to 59 years & $14(8.3)$ & $18(6.9)$ \\
60 to 69 years & $4(2.4)$ & $6(2.3)$ \\
70 to 79 years & & 18 \\
Standard deviation & 18 & 79 \\
Minimum & 79 & $17(27.7)$ \\
Maximum & & $170(65.4)$ \\
Ethnicity & $49(29.1)$ & $13(5)$ \\
White & $104(61.9)$ & $4(1.5)$ \\
Brown & $9(5.4)$ & $1(0.4)$ \\
Black & $6(3.6)$ & \\
Yellow & $0(0.0)$ & $151(58.1)$ \\
Indigenous & & $15(8.9)$ \\
Conjugal Situation & & \\
Single & & \\
Married & & \\
Widow & & \\
\hline
\end{tabular}

\begin{tabular}{|c|c|c|}
\hline Category & HPV positive N (\%) & HPV negative $\mathrm{N}(\%)$ \\
\hline Separated & 15 (8.9) & $24(9.2)$ \\
\hline Consensus Union & $26(15.5)$ & 31 (11.9) \\
\hline \multicolumn{3}{|l|}{ Education } \\
\hline None & $10(6)$ & $12(4.6)$ \\
\hline DK / Refused & $1(0.6)$ & $1(0.4)$ \\
\hline Elementary School & $79(47)$ & $130(50)$ \\
\hline High school & $65(38.7)$ & $78(30)$ \\
\hline Higher education & $13(7.7)$ & $39(15)$ \\
\hline \multicolumn{3}{|l|}{ Income } \\
\hline I do not have income & $17(10.1)$ & $26(10)$ \\
\hline Less than 1 S.M & $49(29.2)$ & $58(22.3)$ \\
\hline 1 to less than 2 S.M & $70(41.7)$ & $116(44.6)$ \\
\hline From 2 to less than $3 \mathrm{~S}$. & 20 (11.9) & $35(13.5)$ \\
\hline $\begin{array}{l}\text { From } 3 \text { to less than } 5 \\
\text { S.M }\end{array}$ & $10(6)$ & $14(5.4)$ \\
\hline 5 to less than 10 S.M & $2(1.2)$ & 5 (1.9) \\
\hline DK / Refused & $0(0.0)$ & $6(2.3)$ \\
\hline \multicolumn{3}{|l|}{$\begin{array}{l}\text { Carry out the last } \\
\text { preventive exam }\end{array}$} \\
\hline 1 year or less & $64(38.1)$ & $103(39.6)$ \\
\hline More than 1 year & $87(51.8)$ & $120(46.2)$ \\
\hline Never & $12(7.1)$ & $18(6.9)$ \\
\hline Do not know & $5(3)$ & $19(7.3)$ \\
\hline \multicolumn{3}{|l|}{ IST History } \\
\hline Yes & $11(6.5)$ & $13(5)$ \\
\hline No & 157(93.5) & $247(97)$ \\
\hline Category & $168(100)$ & $260(100)$ \\
\hline
\end{tabular}

After relating the cofactors with the presence of HPV infection (Table 2), an association of HPV with the following variables was observed: use of oral contraceptives $(p<0.016)$ and alcohol use $(p<0.038)$. The prevalence of HPV was higher in the group that reported using oral contraceptives as a contraceptive method and in those who did not have any alcohol habits. The association between results for HPV and age showed a higher frequency of HPV positive in women older than 25 years (88.7\%). There was a higher prevalence of the HPV virus in women who admitted to having had up to 5 sexual partners during the life (93.4\%), until 3 pregnancies $(71.4 \%$ ) and with the cytopathological result within the limits of normality (61.9\%), however, there was no statistical significance. Through the relationship between the human papillomavirus infection and the risk factors for cervical cancer, it was possible to verify that the majority of women were not smokers independent of the result for HPV infection.

Regarding cytopathologic reports (Table 3), HPV was identified in $40.3 \%(104 / 258)$ of the women with results within the limits of normality and $37,6 \%$ (64/170) of women with some type of alteration identified. The types of alterations found were inflammation in $39.7 \%$ (158/428), atypical squamous cells of 
undetermined significance - ASC-US in 2.1\% (9/428), atypical glandular cells - AGC in $0.5 \%$ (2/428), and atypical squamous cells not excluding intraepithelial lesion - ASC-H in $0.23 \%$ (1/428).

Table 2. Human papillomavirus infection and risk factors for cervical cancer in asymptomatic women in northeastern Brazil.

\begin{tabular}{|c|c|c|c|c|c|}
\hline Variable & & $\begin{array}{r}\mathrm{HPV}+ \\
\mathrm{N}\end{array}$ & $\begin{array}{l}\text { HPV- } \\
\text { N }\end{array}$ & OR (Cl 95\%) & P-value \\
\hline \multicolumn{6}{|l|}{ Age } \\
\hline Less than 25 & & 19 & 21 & $\begin{array}{r}1.45 \\
(0.75-2.78)\end{array}$ & 0.308 \\
\hline More than 25 & & 149 & 239 & & \\
\hline \multicolumn{6}{|c|}{$\begin{array}{l}\text { First Sexual Relationship } \\
\text { (years) }\end{array}$} \\
\hline Under 15 & & 33 & 41 & $\begin{array}{r}1.31 \\
(0.79-2.17)\end{array}$ & 0.360 \\
\hline Greater than 15 & & 135 & 219 & & \\
\hline \multicolumn{6}{|c|}{ Number of Partners } \\
\hline Up to 5 & & 157 & 243 & $\begin{array}{r}1.00 \\
(0.46-2.19)\end{array}$ & 1.000 \\
\hline More than 5 & & 11 & 17 & & \\
\hline $\begin{array}{l}\text { Use of } \\
\text { Contraceptives }\end{array}$ & Oral & & & & \\
\hline Yes & & 37 & 33 & $\begin{array}{r}1.94 \\
(1.15-3.26)\end{array}$ & 0.016 \\
\hline No & & 131 & 227 & & \\
\hline \multicolumn{6}{|l|}{ Smoking } \\
\hline Yes & & 23 & 25 & $\begin{array}{r}1.49( \\
0.82-2.72)\end{array}$ & 0.211 \\
\hline No & & 145 & 235 & & \\
\hline \multicolumn{6}{|l|}{ Ethicism } \\
\hline Yes & & 59 & 66 & $\begin{array}{r}1.59 \\
(1.04-2.43)\end{array}$ & 0.038 \\
\hline No & & 109 & 194 & & \\
\hline \multicolumn{6}{|l|}{$\begin{array}{l}\text { Cytopathological } \\
\text { Result }\end{array}$} \\
\hline Normal & & 164 & 253 & $1.13(0.33-3.94)$ & 1.000 \\
\hline Changed & & 4 & 7 & & \\
\hline
\end{tabular}

Table 3. Cytopathological reports of asymptomatic women according to the type of alteration found

\begin{tabular}{lr}
\hline Type of Change & $\mathbf{N}(\%)$ \\
\hline Inflammation & $158(36.9)$ \\
ASC-US & $9(2.1)$ \\
AGC-US & $2(0.5)$ \\
ASC-H & $1(0.2)$ \\
Total & $170(39.7)$ \\
\hline
\end{tabular}

\section{DISCUSSION}

The detection of HPV infection in SUS users with more sensitive and specific techniques to complement cytology may provide better screening ${ }^{10}$. In our study were identified by the PCR method, $39.2 \%$ ( $n=168$ ) positive, a higher frequency than in the Souza study $(2016)^{11}$, in which $16.3 \%$ of tested women were HPV positive by the PCR method. Although estimates vary by population, efforts have been made to know the incidence of this virus, considering that HPV is what most induce new cancers nowadays. Associated with knowledge of other cancer risk factors, it can enable close monitoring in order to improve diagnostic accuracy and more effective prevention.

The age distribution demonstrated that the most prevalent were women over the age of 25 years old, including those with cervical HPV infection, belonging to the risk group for cervical cancer incidence that is evidenced in young women between 20-29 years old and with higher risk between 4549 years old ${ }^{12}$. In this study, the HPV positivity showed that the age group over 25 years old is also more frequent, since in women under 30 years of age, most HPV infections regress spontaneously; however, in women over the age of 40, this infection may become persistent ${ }^{12}$. A low socioeconomic and educational level was observed in both women with positive detection for HPV and those with negative results. Women with low socioeconomic status are at increased risk group for cervical HPV infection attributed to lack of screening, treatment of precancerous lesions, and knowledge of the prevalence of this infection ${ }^{13}$.

There was an expressive number of married women with HPV infection (44.6\%). This fact may be due to exposure to infectious diseases due to sexual intercourse without using barrier methods ${ }^{14}$. The early onset of sexual life, the greater number of partners, multiparity, and smoking habits showed no significant relation with the positive detection of HPV. However, in other populations, behavioral factors such as multiple partners and early onset of sexual activity influence the risk of HPV infection ${ }^{15,16}$, since they increase the likelihood of finding an infected partner. Multiparity is also associated with HPV infection due to pregnancy-induced hormonal changes facilitating direct exposure of the virus and other co-factors ${ }^{17}$. Smoking has been considered as one of the risk factors for cervical cancer because it interferes with the prevalence of HPV infection $^{18}$.

Regarding the use of oral contraceptives, the frequency was higher in those who reported using it as a contraceptive method. Studies suggest that oral contraceptives may act as an important co-factor in the risk of cervical cancer in women with cervical HPV positivity ${ }^{19}$. Hormones present in oral contraceptives may alter the susceptibility of cervical cells to infection, affecting their ability to fight infection or facilitate HPV infection causing changes that progress to cervical cancer ${ }^{20}$.

HPV detection in women with cytopathologic findings within the limits of normality was $40.3 \%$ (104/258). In our study, the prevalence of HPV was higher than that found by Vieira et al. ${ }^{21}$, with university students from the northern region of 
Brazil, in which the prevalence of HPV in women with normal cytology was $23.4 \%$ (53/227). The overall prevalence of cervical HPV infection in normal cytologies in meta-analyse showed prevalence estimated between $8.4 \%$ and $29 \% 22$. The presence of HPV in women with cytology within the limits of normality suggests clinical latency and may evolve to spontaneous clearance, or depending on the risk factors in which it will be exposed, develop neoplastic lesions in the cervix ${ }^{23}$.

Among the benign cellular alterations, inflammation was the most frequent finding of the cytopathological exams, corroborating with other studies. This inflammatory process impairs the quality of the sample, so it is necessary to perform the treatment to reduce the risk of lameness unsatisfactory ${ }^{24}$. Inflammatory processes in the cervix act in the transformation zone, stimulating the development of squamous metaplasia, favoring cervical oncogenesis, since these cells are more permissive to HPV infection and its replication ${ }^{25}$.

The result of atypical squamous cells of undetermined significance (ASC-US) is an expression of diagnostic uncertainty between normal and low-grade intraepithelial lesion ${ }^{26}$ and ASC-H are atypical signs of undetermined significance in squamous cells, suggestive, but not diagnostic of intraepithelial lesion of high grade ${ }^{27}$. Our study also identified atypical, mostly transient, but some may indicate a pre-malignant condition or more rarely invasive cancer ${ }^{28}$. Cellular atypia of glandular cells was frequent in $0.5 \%$ of the population, which corroborates with studies, in which the incidence ranges from $0.1 \%$ to $0.8 \%$ 35. The finding of this atypia is important because the number of cases associated with pre-malignant lesions and cervical cancer is higher than for ASC-US ${ }^{29}$.

Screening for HPV cervical infection is an important diagnostic finding, which is associated with the identification of other risk factors for a particular population, may provide more effective preventive measures and consequently stop the development of cervical cancer. More effective screening with more sensitive detection techniques, less susceptible to errors due to the subjectivity of the analysis, would be more effective tools to reduce the high incidence by potentiating early treatments, reducing the development of new cases of cervical neoplasia.

\section{CONCLUSION}

In this study, we identified that $39.2 \%$ of the women had an HPV infection. Interestingly, a high frequency of infected women presented cytopathological examination results within the limits of normality, suggesting clinical latency. Thus, a prospective cohort study with this population would contribute to a better analysis of co-factors for the development of HPV infection. The variables that showed a relation to HPV positive and consequent risk factors for the development of cervical cancer were: alcoholism and the use of oral contraceptives.

This research favors the assistance to the woman directed to the prevention of these diseases, the sensitization of the population on the need for behavior change, and strengthening of knowledge about prevention and screening of cervical cancer. It should be noted that the insertion of HPV identification into the routine of the SUS would provide better screening of women who are at greater risk for the development of cervical cancer. The study reinforces the important role of HPV detection and risk factors related to susceptibility to cervical oncogenesis, suggesting that this type of cancer could be potentially preventable, since the risk factors are mostly controllable, and it is necessary to propose interventions that aim at the health education of this population, actions of prevention and early detection with the aid of molecular detection. Screening for the HPV virus is important to prevent the course of infection and subsequent development of cervical cancer and even in the pathology tracking system, the incidence is still high, so early detection enhances healing, avoiding the development of new cases of cervical neoplasia.

\section{ACKNOWLEDGEMENTS}

We thank the collaborators of the project "Integrated Actions in Adult Health: focusing on Health Surveillance and Sexually Transmitted Diseases", to the employees of the Basic Health Units, the Municipal Health Department, and the Arapiraca City Hall.

\section{REFERENCES}

1. World Health Organization. Comprehensive cervical cancer prevention and control: a healthier future for girls and women. Geneve: WHO; 2013.

2. IARC Working Group on the Evaluation of Carcinogenic Risks to Humans. Human papillomaviruses. IARC Monogr Eval Carcinog Risks Hum [Internet]. 2007 [cited 2018 Nov 24];90: 1-636. Available from: http://www.ncbi.nlm.nih. gov/pubmed/18354839.

3. World Health Organization. Human papillomavirus (HPV) and cervical cancer [Internet]. Geneve: WHO; 2016 [cited 2018 Nov 24]. Available from: http:// www.who.int/news-room/fact-sheets/detail/human-papillomavirus-(hpv)-andcervical-cancer.
4. Bzhalava D, Eklund C, Dillner J. International standardization and classification of human papillomavirus types. Virology [Internet]. 2015 Feb [cited 2019 Jun 2]; 476: 341-4. Available from: http://www.ncbi.nlm.nih.gov/pubmed/25577151.

5. Coelho PLS, Calestini GLS, Alvo FS, Freitas JMM, Castro PMV, Konstantyner T. Segurança da vacina papillomavirus humano 6, 11, 16 e 18 (recombinante): revisão sistemática e metanálise. Rev Paul Pediatr. 2015; 33(4): 474-82. doi: http://dx.doi.org/10.1016/j.rpped.2015.02.006.

6. Ferlay J, Soerjomataram I, Dikshit R, Eser S, Mathers C, Rebelo M, et al. Cancer incidence and mortality worldwide: Sources, methods and major patterns in GLOBOCAN 2012. Int J Cancer [Internet]. 2015 Mar [cited 2018 Nov 24]; 136(5): 
E359-86. doi: 10.1002/ijc.29210. Available from: http://www.ncbi.nlm.nih.gov/ pubmed/25220842.

7. Instituto Nacional de Câncer José Alencar Gomes da Silva. Estimativa 2016: incidência de câncer no Brasil [Internet]. Rio de Janeiro: INCA; 2015 [cited 2018 Jul 1]. 122p. Available from: https://santacasadermatoazulay.com.br/wpcontent/uploads/2017/06/estimativa-2016-v11.pdf.

8. Wong HYM, Loke AY, Chan NHL. Risk Factors for Cervical Abnormalities Among Hong Kong Chinese Women: A Large-Scale Community-Based Cervical Screening Program. J Women's Heal [Internet]. 2011 Jan [cited 2018 Nov 24]; 20(1): 53-9. Available from: http://www.ncbi.nlm.nih.gov/pubmed/21091197.

9. Nayar R, Wilbur DC. The Pap test and Bethesda 2014. Cancer Cytopatho [Internet]. 2015 May 1 [cited 2018 Nov 24];123(5): 271-81. Available from: http://doi.wiley.com/10.1002/cncy.21521.

10. Kenne EL, Gassen M, Santos CE, Reis LN, Bullé DJ, Renner JDP. Diagnóstico molecular de HPV em amostras cérvicovaginais de mulheres que realizam o papanicolaou. Cinergis [Internet]. 2014 Dec [cited 2018 Nov 24];15(4): 201206. Available from: https://online.unisc.br/seer/index.php/cinergis/article/ view/5517.

11. Souza NCC. Identificação da prevalência de variantes de papilomavírus humano (HPV) no estado de Alagoas e desenvolvimento de "kit" de detecção e tipificação em amostra biológica [tese] [Internet]. Maceió (AL): Universidade Federal de Alagoas; 2016 [cited 2018 Nov 24]. Available from: http://www. repositorio.ufal.br/handle/riufal/1554

12. Instituto Nacional de Câncer José Alencar Gomes da Silva. Estimativa 2012: incidência de câncer no Brasil [Internet]. Rio de Janeiro: INCA; 2011 [cited 2018 Nov 24]. Available from: http://portal.saude.sp.gov.br/resources/ses/perfil/ gestor/homepage/estimativas-de-incidencia-de-cancer-2012/estimativas incidencia_cancer_2012.pdf.

13. Silva MAS, Teixiera ÉMB, Ferrari RAP, Cestari MEW, Cardelli AAM. Fatores relacionados a não adesão à realização do exame de Papanicolau. Rev Rene [Internet]. 2015 Aug [cited 2019 Jun 2];16(4): 532-9. Available from: http:// periodicos.ufc.br/rene/article/view/2745.

14. Chiconela FV, Chidassicua JB. Conhecimentos e atitudes das mulheres em relação ao exame preventivo do câncer do colo uterino. Rev Eletr Enf [Internet]. 2017 Sep [cited 2018 Nov 24];19(0). Available from: https://www.revistas.ufg. $\mathrm{br} /$ fen/article/view/41334.

15. Schiffman $M$, Wentzensen $N$. Human papillomavirus infection and the multistage carcinogenesis of cervical cancer. Cancer Epidemiol Biomarkers Prev [Internet]. 2013 Apr [cited 2018 Nov 24]; 22(4): 553-60. Available from: http:// www.ncbi.nlm.nih.gov/pubmed/23549399.

16. Liu Z-C, Liu W-D, Liu Y-H, Ye X-H, Chen S-D. Multiple Sexual Partners as a Potential Independent Risk Factor for Cervical Cancer: a Meta-analysis of Epidemiological Studies. Asian Pac J Cancer Prev [Internet]. 2015 [cited 2019 Jun 2];16(9): 3893-900. Available from: http://www.ncbi.nlm.nih.gov/ pubmed/25987056.

17. Jensen KE, Schmiedel S, Norrild B, Frederiksen K, Iftner T, Kjaer SK. Parity as a cofactor for high-grade cervical disease among women with persistent human papillomavirus infection: a 13-year follow-up. Br J Cancer [Internet]. 2013 Jan [cited 2018 Nov 24];108(1): 234-9. doi: 10.1038/bjc.2012.513. Available from: http://www.ncbi.nlm.nih.gov/pubmed/23169283.

18. Mzarico E, Gómez-Roig MD, Guirado L, Lorente N, Gonzalez-Bosquet E. Relationship between smoking, HPV infection, and risk of Cervical cancer. Eur
J Gynaecol Oncol [Internet]. 2015 [cited 2018 Nov 24];36(6): 677-80. Available from: http://www.ncbi.nlm.nih.gov/pubmed/26775350

19. Ghanem KG, Datta SD, Unger ER, Hagensee M, Shlay JC, Kerndt P, et al. The association of current hormonal contraceptive use with type-specific HPV detection. Sex Transm Infect [Internet]. 2011 Aug [cited 2018 Nov 24]; 87(5): 385-8. doi: 10.1136/sextrans-2011-050005. Available from: http://www.ncbi. nlm.nih.gov/pubmed/21772042.

20. IARC Working Group on the Evaluation of Carcinogenic Risks to Humans. Combined estrogen-progestogen contraceptives and combined estrogenprogestogen menopausal therapy [Internet]. IARC Monogr Eval Carcinog Risks Humans. 2007 [cited 2018 Nov 24]. 91: 1-528 p. Available from: http://www. ncbi.nlm.nih.gov/pubmed/18756632.

21. Vieira RC, Monteiro JSV, Manso EP, Santos MRM, Tsutsumi MY, Ishikawa EAY, et al. Prevalence of type-specific HPV among female university students from northern Brazil. Infect Agent Cancer [Internet]. 2015 Jul [cited 2018 Nov 24];10:21. doi: 10.1186/s13027-015-0017-x. .Available from: http://www.ncbi. nIm.nih.gov/pubmed/26203300.

22. Jalilvand S, Shoja Z, Nourijelyani K, Tohidi HR, Hamkar R. Meta-analysis of type-specific human papillomavirus prevalence in Iranian women with normal cytology, precancerous cervical lesions and invasive cervical cancer: Implications for screening and vaccination. J Med Virol [Internet]. 2015 Feb [cited 2018 Nov 24]; 87(2): 287-95. doi: 10.1002/jmv.24053. Available from: http://www.ncbi. nlm.nih.gov/pubmed/25156655.

23. Noronha VL, Noronha R, Carmona B, Macedo LA. Papilomavírus Humano (HPV) em mulheres com citologia oncótica dentro dos limites da normalidade. Control. 2005; 17(1): 49-55.

24. Gusso G, Lopes JMC, Dias LC. Tratado de Medicina de Família e Comunidade - Princípios, Formação e Prática. Porto Alegre: Artmed; 2012. 2222 p.

25. Oliveira MV, Almeida MC. Prevalência de citologia inflamatória cervical em mulheres atendidas pelo laboratório de citologia da Fundação de Saúde de Vitória da Conquista: achados citológicos e agentes causais. C\&D Rev Eletr Fainor [Internet]. 2014 Jan-Jun [cited 2018 Nov 24];7(1): 184-198. Available from: https://biocienciasims.ufba.br/sites/biocienciasims.ufba.br/files/ prevalencia_de_citologia_inflamatoria_cervical_em_mulheres_atendidas_ pelo_laboratorio_de_citologia_da_fundacao_de_saude_de_vitoria_da_ conquista_achados_citologicos_e_agentes_causais.pdf

26. Ministério da Saúde (BR). Controle dos cânceres do colo do útero e da mama. 2.ed. Brasília: Ministério da Saúde; 2013. Cadernos de Atenção Básica, n. $13.124 \mathrm{p}$

27. Selvaggi SM. Clinical significance of atypical squamous cells cannot exclude high grade squamous intraepithelial lesion with histologic correlation-: A 9-Year experience. Diagn Cytopathol [Internet]. 2013 Nov [cited 2018 Nov 24]; 41(11): 943-6. doi: 10.1002/dc.22982.Available from: http://www.ncbi.nlm.nih.gov/ pubmed/23749686

28. Lee H, Lee E-J. HPV infection and p16 promoter methylation as predictors of ASC-US/LSIL progression. Cancer Cytopathol [Internet]. 2016 Jan [cited 2018 Nov 24];124(1): 58-65. doi: 10.1002/cncy.21615. Available from: http://www. ncbi.nlm.nih.gov/pubmed/26335500.

29. Wang J, Andrae B, Sundström K, Ström P, Ploner A, Elfström KM, et al. Risk of invasive cervical cancer after atypical glandular cells in cervical screening: nationwide cohort study. BMJ [Internet]. 2016 Feb [cited 2018 Nov 24]; 352: i276. doi: 10.1136/bmj.i276. Available from: http://www.ncbi.nlm.nih.gov/ pubmed/26869597.

\section{Como citar este artigo/How to cite this article:}

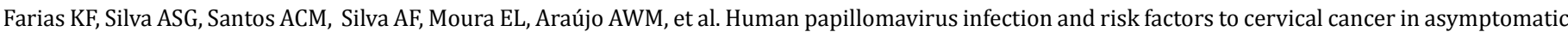
women in the region of the Northeast of Brazil. J Health Biol Sci. 2021; 9(1):1-6. 